\title{
ЮВІЛЕЙНА КОНФЕРЕНЦІЯ ІНСТИТУТУ ПРОФЕСІЙНО-ТЕХНІЧНОÏ ОСВІТИ НАПН УКРАЇНИ, ПРИСВЯЧЕНА ЗО-Й РІЧНИЦІ НЕЗАЛЕЖНОСТІ УКРАЇНИ
}

\author{
https://doi.org/10.37472/2707-305X-2021-3-2-17-8
}

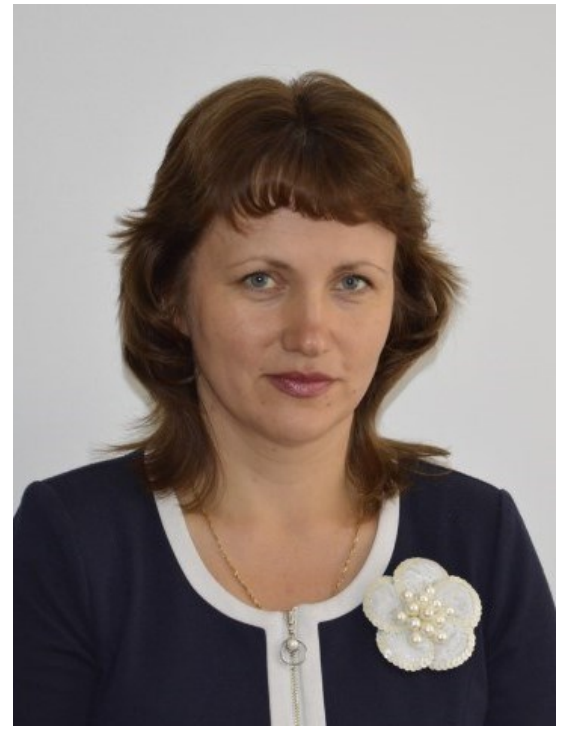

БАЗИЛЬ

Людмила Олександрівна доктор педагогічних наук, дочент, вчений секретар Iнституту профресійнотехнічної освіти Національної академії педагогічних наук України, м. Київ, Україна

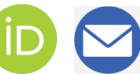

Анотація. У статmі представлено досягнення Інституту професійно-технічної освіти Національної академії педагогічних наук України. Наведено перспективні напрями реалізації провідних завдань Інституту щодо наукового і методичного супроводу інноваційного розвитку системи професійної (професійно-технічної) та фахової передвищої освіти. Схарактеризовано здобутки вчених Інституту професійно-технічної освіти НАПН України у суверенній державі, взаємодію наукової установи з закладами професійної (профресійно-технічної) та фахової передвищої освіти, організаціями-партнерами, стейкхолдерами. Показано конструктивну взаємодію Інституту з навчально-методичними иентрами професійно-технічної освіти у Вінницькій, Волинській, Дніпропетровській, Донецькій, Закарпатській, Кіровоградській, Київській, Луганській, Львівській, Миколаївській, Одеській, Сумській, Харківській, Черкаській областях, що здійснюється 15 років згідно з укладеними угодами. Звернуто увагу на ключові завдання, які постають перед сучасною системою професійної (профресійно-технічної) та фахової передвищої освіти, та ії пріоритети, що зумовлені утвердженням незалежності нашої країни.

Ключові слова: профресійна освіта; професійно-технічна освіта; фрахова передвища освіта; Інститут професійно-технічної освіти НАПН України; науково-методичний супровід.

Якісна професійна освіта - запорука й характерна ознака успішного розвитку суверенної України як самодостатньої держави, ефективний спосіб розкриття творчого потенціалу їі громадян. Створений за розпорядженням Кабінету Міністрів України у п'ятнадцяту річницю незалежності України Інститут професійно-технічної освіти Національної академії педагогічних наук України з метою проведення фундаментальних і прикладних досліджень, спрямованих на розв'язання актуальних теоретичних і методологічних проблем педагогіки і психології професійної (професійно-технічної) освіти, успішно реалізує означені цілі.

Цьогоріч у рамках ювілейної XV Всеукраїнської науковопрактичної (звітної) конференції «Науково-методичне забезпечення професійної освіти і навчання», присвяченої 30-й річниці Незалежності України, обговорено низку важливих питань щодо реформування професійної освіти в Україні. Науково-практичний захід організовано в співпраці Національної академії педагогічних наук України, Міністерства освіти і науки України, Конфедерації роботодавців України. Незважаючи на онлайн-формат проведення заходу, у зв'язку зі складною епідемічною ситуацією в країні та карантинними обмеженнями, виразними його характеристиками стали інтенсивність обговорення й творча взаємодія учасників заходу. 
У вебінарах, що проводилися в рамках звітної конференції з 15 березня до 23 березня 2021 р., взяли участь понад тисячу учасників із усіх областей України, зокрема: представники органів влади і місцевого самоврядування, стейкхолдери, керівники і методисти науково (навчально)методичних центрів (кабінетів) професійної (професійно-технічної) освіти, директори і педагоги освітніх інституцій, науковці й здобувачі наукових і науково-освітніх ступенів.

Зацікавленість широкої освітньо-наукової аудиторії свідчить про масштабний характер заходу, його актуальність, затребуваність та своєчасність. Нестандартний, онлайн-формат проведення конференції уможливив багаторазовий перегляд відеовиступів учених ІПТО НАПН України, представників Міністерства освіти і науки України, Національної академії педагогічних наук України, Конфедерації роботодавців України, Інституту професійних кваліфікацій, керівників та методистів науково (навчально)методичних центрів професійно-технічної освіти, педагогів закладів професійної (професійнотехнічної) освіти, які $€$ активними партнерами наукової установи в забезпеченні модернізації професійної і фахової передвищої освіти.

у відеодоповіді «Наукова платформа професійної освіти: сталий розвиток» директора Інституту професійно-технічної освіти НАПН України, доктора педагогічних наук, професора, дійсного члена (академіка) НАПН України Валентини Радкевич зосереджено увагу на глибоких змінах професійної (професійно-технічної) освіти України, що характеризуються:

- реформуванням системи управління закладами освіти;

- створенням їх нової архітектури та системи взаємодії;

- диверсифікацією джерел фінансування;

- зростанням ролі автономії закладів освіти, запитами на розроблення та впровадження нових форм і методів організації освітнього процесу (зокрема, елементів дуальної, дистанційної освіти);

- зміною форм взаємодії між стейкхолдерами в рамках державно-приватного партнерства;

- зростаючими вимогами до змісту та якості освіти;

- актуалізацією ролі науково-експериментальної, аналітичної дорадчої діяльності представників освітньої спільноти.

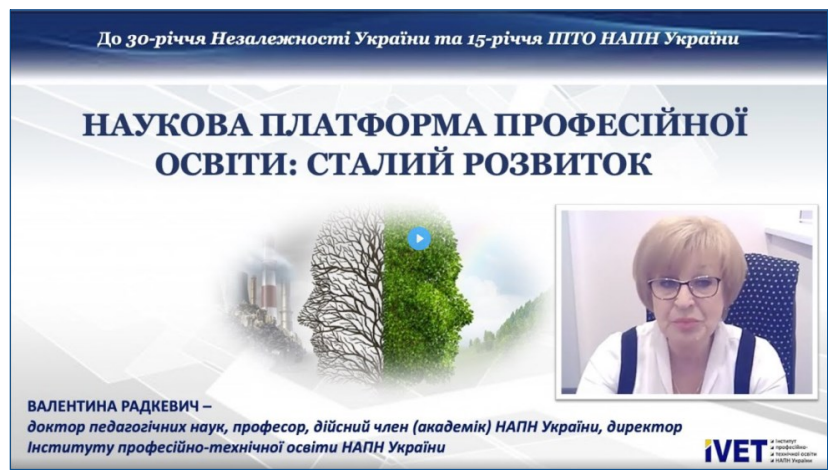

у цьому контексті актуалізовано значення наукових установ, покликаних забезпечувати якісний науково-методичний супровід модернізації сучасної професійної освіти.

«нститут професійно-технічної освіти НАПН України вже 15 років $є$ надійною науковою платформою всіх вищезазначених модернізаційних змін і єдиною в Україні науковою установою, що здійснює науково-методичний супровід закладів професійної (професійно-технічної) та фахової передвищої освіти», - слушно констатує Валентина Радкевич, здійснюючи аналітичний огляд здобутків наукової установи за 15 років. Доповідач наголосила, що в Інституті підготовлено 1724 види наукової продукції; 128 - виробничопрактичної; 77 - навчальної; 38 - довідкової. До Електронної бібліотеки НАПН України за 15 років завантажено понад 2 тис. ресурсів і зафіксовано більше 200 тис. їх завантажень. Інтерес до наукових напрацювань Інституту визначається системою рейтингів, а саме: Індекс Хірша Інституту в Google Scholar - 48, «10-індекс» - 290. «При цьому, - зауважила Валентина Радкевич, наукова продукція зорієнтована на всебічну реалізацію Цілей Сталого Розвитку, а саме:

- сприяння розвитку малого бізнесу шляхом формування в учнівської молоді підприємницької та кар'єрної компетентностей;

- підвищення якості освіти;

- інтернаціоналізацію професійної освіти на основі вивчення й поширення зарубіжного досвіду;

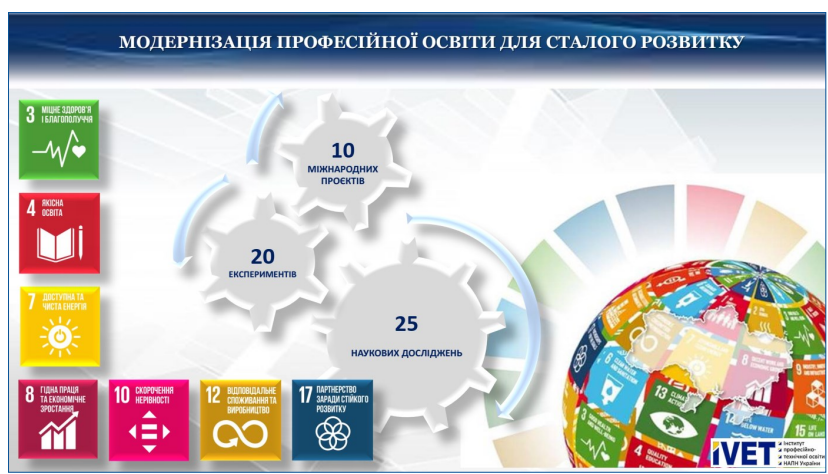


- вдосконалення цифрових компетентностей суб'єктів освітнього процесу;

- розвиток дистанційної та дуальної форми здобуття освіти;

- впровадження проєктного навчання;

- удосконалення підготовки педагогічних кадрів тощо.

«Приємно, - відмітила керівник установи, що за 15 років в Інституті розроблено майже 200 інновацій, із них: 20 - концепцій і моделей, більше - 40 методик і технологій та десятки інших наукових розробок для системи П(ПТ)О із 15 напрямів модернізації професійної та фахової передвищої освіти». Наприкінці доповіді Валентина Радкевич звернулася до учасників конференції зі словами вдячності й підкреслила: «Ніколи соціально-економічні чи пандемічні проблеми не обмежували нашу діяльність, оскільки ґрунтувалася вона на засадах наукової організації праці та відданості членів колективу». Виголошуючи щиру подяку НАПН України, Відділенню професійної освіти і освіти дорослих, особисто президенту В.Г. Кременю та академіку-секретарю відділення Н.Г. Ничкало за підтримку інноваційних наукових пошуків, наголосила: «Всі ми згуртовані єдиною метою - через наукові дослідження зміцнювати наукову платформу модернізації професійної та фахової передвищої освіти, сприяти сталому розвитку нашої країни, суспільства й системи освіти в цілому. Ця єдність є запорукою наших майбутніх успіхів, у що ми всі щиро віримо». Відеовиступ можливо переглянути на офіційному сайті Інституту та на каналі Youtube за посиланням (Радкевич, 2021a; Радкевич, 2021b).

У доповіді Василя Кременя, президента Національної академії педагогічних наук України, доктора філософських наук, професора, дійсного члена (академіка) НАН України і НАПН України «Науковий супровід інноваційного розвитку професійної освіти» схарактеризовано досягнення Інституту професійно-технічної освіти НАПН України як перспективні здобутки модернізації підсистеми професійної освіти. Наскрізна ідея відеовиступу академіка втілена в сентенції: «Професійна освіта - була, $\epsilon$ і залишиться в майбутньому надзвичайно важливою сферою і підсистемою освітньої галузі, оскільки здійснює підготовку фахівців для базових сфер економіки, фахівців, які $\epsilon$ «молодшими командирами» на виробництві». Розкривши наріжні щаблі інноваційного розвитку професійної освіти у майбутньому і перспективні напрями його наукового супро-

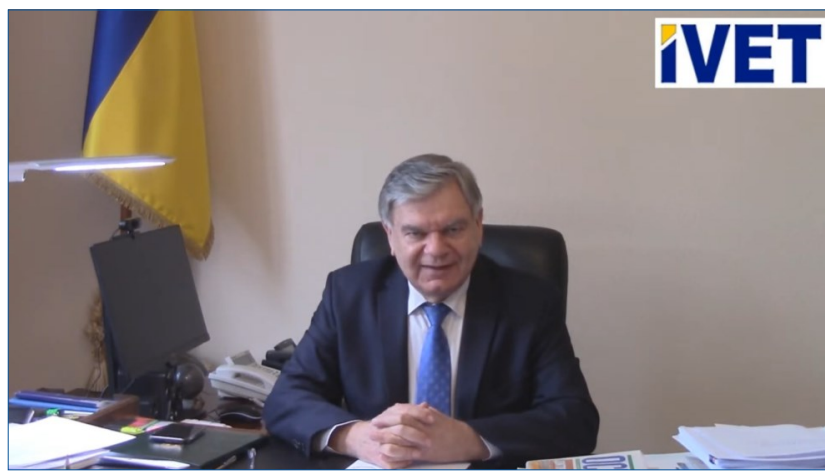

воду, Василь Кремень привітав колектив науковців Інституту професійно-технічної освіти НАПН України, очолюваний Валентиною Радкевич, та побажав ученим професійних успіхів, нових звершень, реалізації креативних ідей, миру і процвітання в рідній державі. Відео доступне за посиланням (Кремень, 2021).

П’ятнадцятирічну історію методологічного і професійного зростання Інституту професійнотехнічної освіти НАПН України відтворила у неординарному відеовиступі Нелля Ничкало, академік-секретар Відділення професійної освіти і освіти дорослих НАПН України, доктор педагогічних наук, професор, дійсний член (академік) НАПН України. Характеризуючи здобутки академічного інституту, вчена зосередила увагу на основних результатах продуктивної взаємодії науки і практики, особливостях розвитку науково (навчально)-методичних центрів і закладів професійної (професійно-технічної) освіти, експериментальних майданчиків, що здійснюється за постійного науково-методичного супроводу колективу Інституту професійно-технічної освіти НАПН України, й зазначила: «У цій співпраці відчувається велика відданість науковців системі професійної (професійно-технічної) освіти, глибинне розуміння проблем цієї системи і максимальне прагнення допомогти цій системі». Здійснюючи ретроспективний аналіз історії становлення Інституту професійно-технічної освіти НАПН України Нелля Ничкало розкрила цікаві історичні факти й передумови становлення академічної

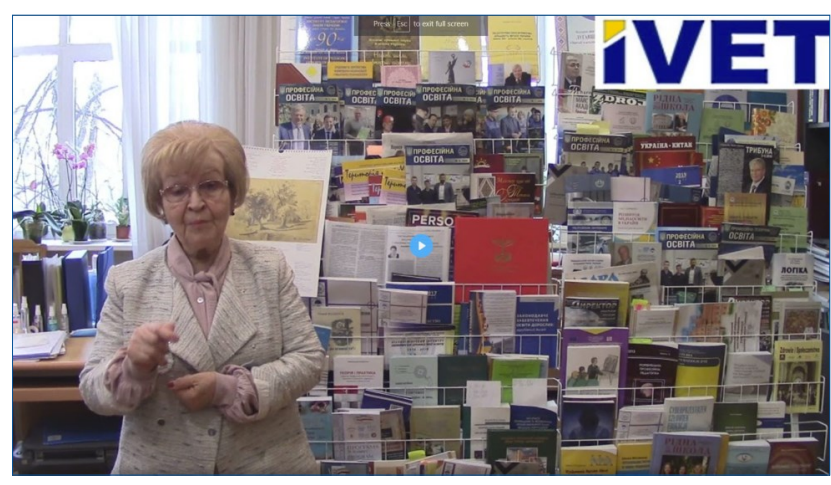


установи, правдиво відтворила прагнення й сподівання наукової та освітянської спільнот, схарактеризувала основні ознаки прогресивного поступу, а також спрогнозувала пріоритетні напрями модернізації професійної (професійнотехнічної) освіти. Переглянути відеовиступ Неллі Ничкало можна за посиланням (Ничкало, 2021).

«Цьогоріч проведення звітної конференції Інституту професійно-технічної освіти НАПН України має символічний характер, оскільки ювілейна дата створення наукової установи збігається з 30-ю річницею Незалежності України, і це дає змогу окреслити основні проблеми розвитку професійної (професійно-технічної) освіти та визначити ефективні шляхи їх вирішення» розпочав відеовиступ Олексій Мірошніченко, виконавчий віце-президент Конфедерації роботодавців України. Доповідач закцентував увагу на нових видах зайнятості населення, а саме: «дистанційна робота», «надомна робота», «контракт з нульовою зайнятістю» і «домашня робота», що потребують відповідних компетенцій і кваліфікацій. Учений окреслив перспективні вектори співпраці наукових установ й освітніх інституцій у забезпеченні дієвої модернізації підсистеми професійної освіти відповідно до сучасних трендів суспільного поступу. Перегляд і коментування виступу доступні за посиланням (Мірошніченко, 2021).

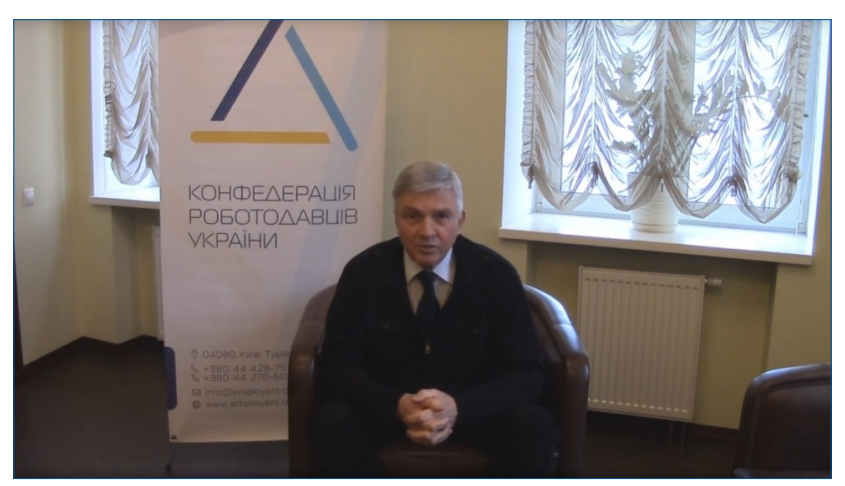

Про основні наукові підходи в реалізації державної політики у сфері професійної освіти йшлося у відеовиступі Ірини Шумік, генерального директора Директорату професійної освіти Міністерства освіти і науки України, кандидата наук з державного управління. Підводячи підсумки модернізації професійної (професійно-технічної) освіти за 30 років існування Незалежної України, представник Міністерства підкреслила значення Інституту в розробленні «Концепції реалізації державної політики у сфері професійної (професійно-технічної) освіти «Сучасна професій-

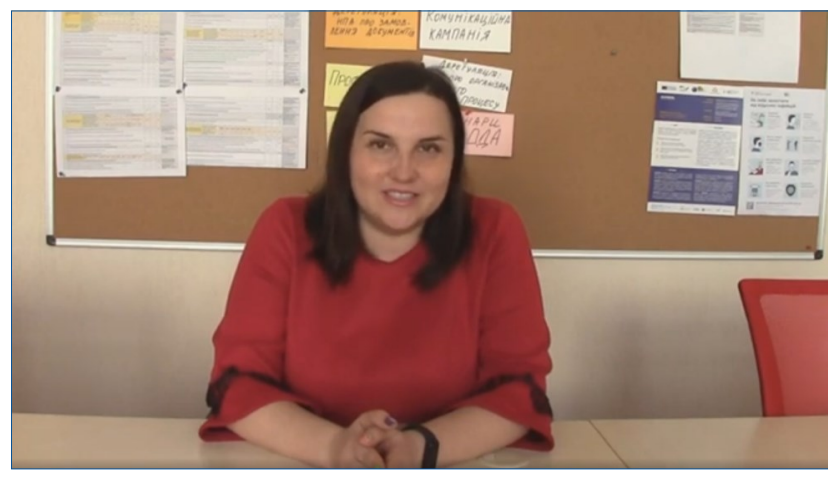

на (професійно-технічна) освіта» на період до 2027 року» (Кабінет Міністрів України, 2019), «Стратегії розвитку професійно-технічної освіти до 2023 року» (Урядовий портал, 2020). «Зміни, які сьогодні відбуваються в Україні, напряму залежать від науки і реалізації наукових підходів у державній політиці», - зазначила наприкінці виступу Ірина Шумік і побажала колективу науковців ІПТО НАПН України плідної роботи і нових наукових звершень на благо України і професійної освіти. Відеовиступ для перегляду та коментування доступний за посиланням (Шумік, 2021).

У доповіді на тему: «Методична і практична підтримка діяльності закладів професійної освіти в сучасних умовах» Катерини Мірошниченко, президента Всеукраїнської асоціації працівників професійно-технічної освіти, експерта Міжнародного проєкту «EU4Skills: кращі навички для сучасної України», зосереджено увагу на трьох напрямах діяльності, які поєднують Всеукраїнську асоціацію працівників професійно-технічної освіти та Інститут професійно-технічної освіти НАПН України, а саме:

- робота над формуванням сучасної нормативно-правової бази, яка $б$ регулювала діяльність професійної освіти;

- підвищення кваліфікації педагогічних кадрів і формування нової наукової спільноти у педагогічних працівників закладів професійної освіти;

- забезпечення соціально-економічних прав учасників освітнього процесу.

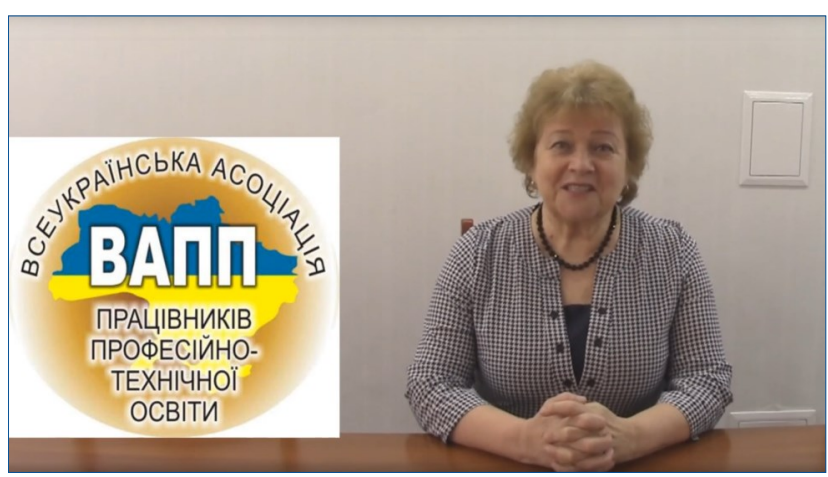


Переглянути відеовиступ можна за посиланням (Мірошніченко, 2021).

Щирими словами вдячності розпочав відеовиступ на тему «Науково-методичний супровід експериментальної роботи закладів професійної (професійно-технічної) освіти Дніпропетровської області» Віктор Василиненко, директор Навчально-методичного центру професійно-технічної освіти у Дніпропетровській області. Схарактеризувавши інноваційні вектори конструктивної співпраці науковців Інституту і педагогів-практиків закладів професійної освіти, він висловив сподівання на подальшу плідну взаємодію й реалізацію спільних стратегічних планів успішного розвитку освітніх інституцій у Дніпропетровській області. Переглянути відеозвернення можна за посиланням (Василиненко, 2021).

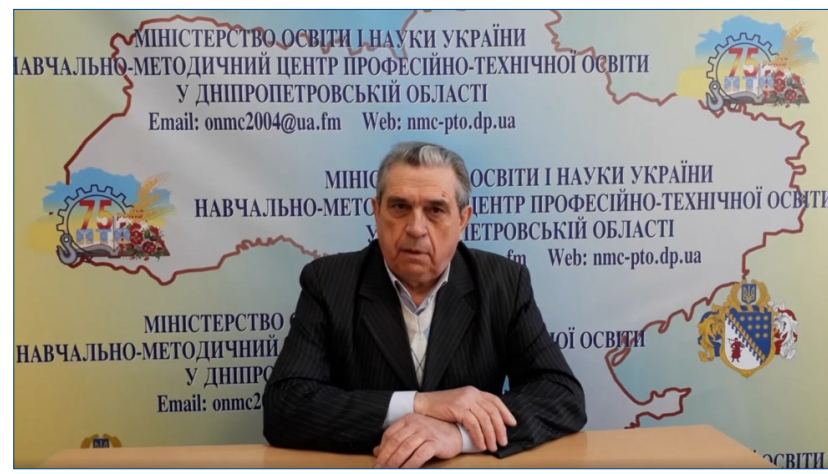

Досвід упровадження проєктного менеджменту у професійну підготовку майбутніх кваліфікованих робітників Донецької області висвітлив у виступі Едуард Гончаров, директор Навчально-методичного центру професійно-технічної освіти у Донецькій області. "У сучасних умовах потужного реформування професійної освіти, постійного зростання вимог до кваліфікації робітників та ефективності їхньої підготовки, у час швидкого розвитку цифрових технологій, чому сприяло дистанційне і змішане навчання, особливої актуальності набувають питання інформаційноаналітичного забезпечення управлінського та освітнього процесів, а ефективне управління інформаційними потоками є конкурентною перевагою функціонування закладів освіти усіх типів і видів, у тому числі і закладів професійної освіти» зазначив на початку виступу очільник центру. У виступі Едуард Гончаров детально охарактеризував інноваційний досвід функціонування закладів професійної освіти Донецької області, що відбувається за науково-методичного супроводу співробітників Інституту професійно-технічної

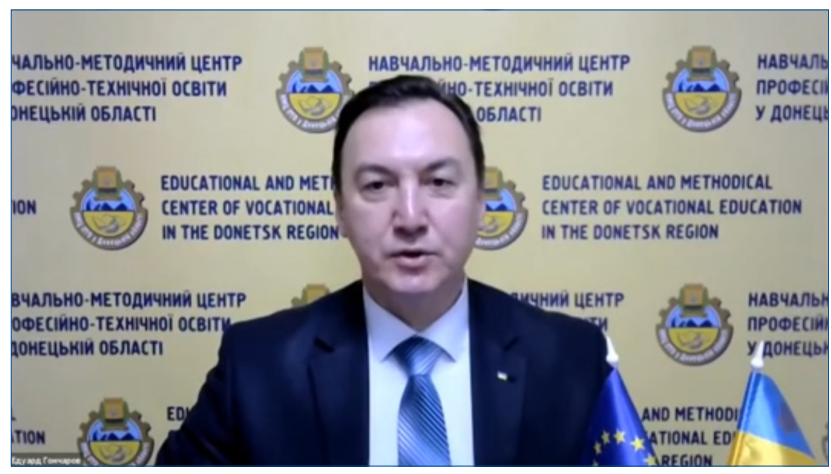

освіти НАПН України. Перегляд відеовиступу доступний за посиланням (Гончаров, 2021).

Висвітленню здобутків Інституту професійнотехнічної освіти НАПН України щодо розвитку проєктного менеджменту та забезпечення науково-методичного супроводу реалізації приватнопублічного партнерства й розширення впровадження проєктно-грантової діяльності як одного зі стратегічних варіантів розвитку Луганщини присвячено доповідь Ольги Лебединської, методиста Навчально-методичного центру професійнотехнічної освіти у Луганській області. Масштабна проєктна діяльність ЗП(ПТ)О, що здійснюється за науково-методичного супроводу науковців Інституту професійно-технічної освіти НАПН України і сприяє підвищенню ефективності та якості освітнього процесу, оновленню й удосконаленню освітніх програм, підвищенню іміджу робітничих професій, залученню до навчання вразливих і соціально незахищених груп населення, вихованню в учнівської молоді лідерських здібностей, соціальної активності, наданню своєчасної психологічної підтримки тощо, а також уможливлює оновлення матеріально-технічної бази, покращення якості навчання здобувачів освіти, збільшення їх конкурентоздатності на ринку праці. Відеовиступ для перегляду та коментування доступний за посиланням (Лебединська, 2021).

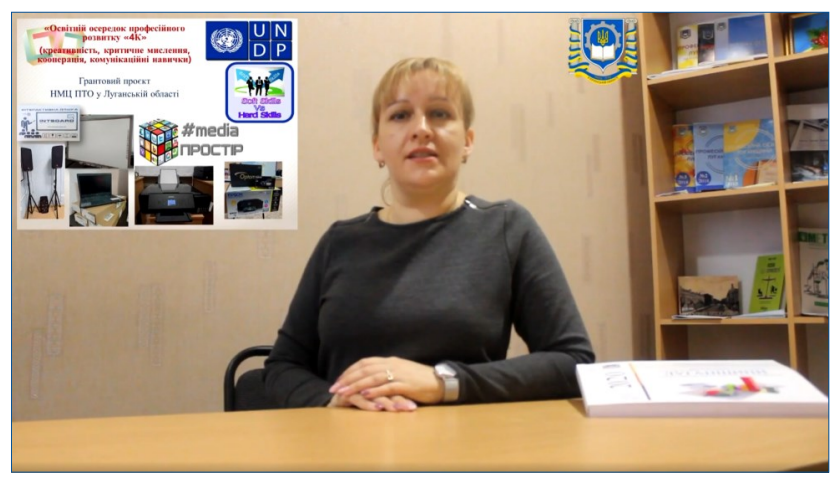

Практико-орієнтованістю й інноваційною випереджувальністю взаємодій наукової установи із закладами освіти характеризувалися виступи: 
- «Напрями конструктивної взаємодії науки й освітньої практики у Сумській області» Павла Помарана, директора Державного професійнотехнічного навчального закладу «Роменське вище професійне училище» (Помаран, 2021);

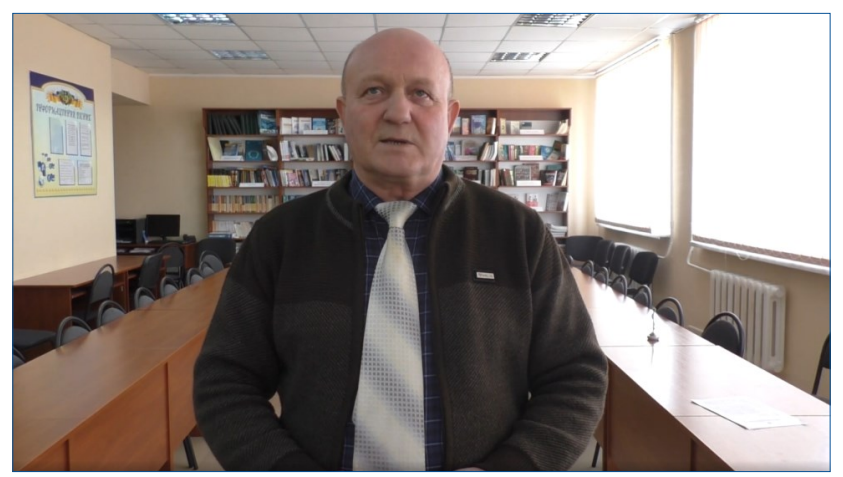

- «Партнерство Інституту професійно-технічної освіти НАПН України і НМК ПТО у Київській області - симбіоз науки і практики» Марини Cmaceєвої, директора Навчально-методичного кабінету професійно-технічної освіти у Київській області (Стасєєва, 2021).

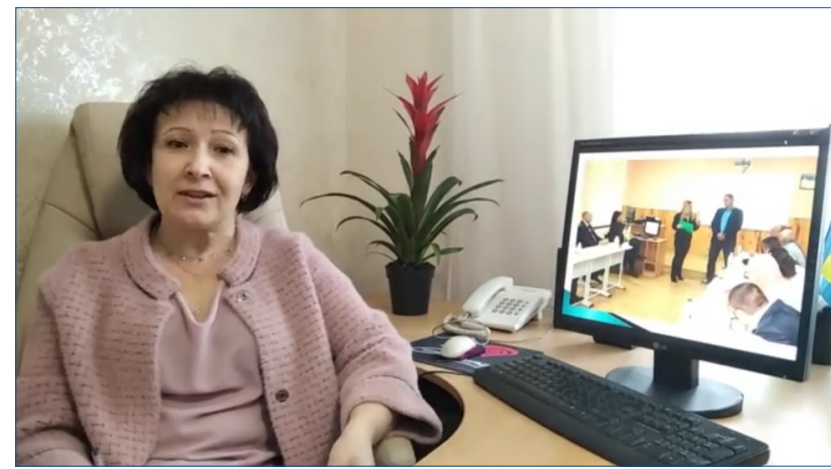

Проведена у відеоформаті ювілейна звітна конференція Інституту професійно-технічної освіти НАПН України «Науково-методичне забезпечення професійної освіти і навчання» стала плідною стосовно представлених наукових і практичних результатів, й мала виразне інноваційне випереджувальне спрямування.

Сподіваємося, що матеріал, висвітлений у відео виступах і доступний на офіційному сайті наукової установи та каналі Youtube, буде дієвим і корисним для представників науково-освітянської спільноти, які переймаються проблемами реформування професійної (професійно-технічної) і фахової передвищої освіти.

\section{СПИСОК ВИКОРИСТАНИХ ДЖЕРЕЛ}

Василиненко, В.М. (2021, 25 березня). Науковометодичний супровід експериментальної роботи закладів професійної (професійно-технічної) освіти Дніпропетровської області [Відео]. YouTube. https://youtu.be/NJFspNtu7ck

Гончаров, Е.В. (2021, 25 березня). Досвід упровадження проектного менеджменту у професійну підготовку майбутніх кваліфікованих робітників Донецької області [Відео]. YouTube. https:// youtu.be/7IWsL3b5GUs

Інститут професійно-технічної освіти НАПН України. (2021, 15-26 березня). Науково-методичне забезпечення професійної освіти і навчання. XV Всеукраїнська науково-практична конференція до 30 ти річчя Незалежності України та 15-ої річниці від дня заснування Інституту профресійнотехнічної освіти НАПН України. https:// www.ivet.edu.ua/index.php/events/khv-

vseukrayinska-naukovo-praktychna-konferentsiya

Кабінет Міністрів України. (2016, 27 березня). Про утворення Інституту професійно-технічної освіти (160-p). https://zakon.rada.gov.ua/laws/ show/160-2006-p

Кабінет Міністрів України. (2019, 12 червня). Про схвалення Кониепиії реалізації державної політики у сфрері професійної (профресійно-технічної) освіти "Сучасна професійна (професійно-технічна) освіта» на період до 2027 року (419-p). https:// zakon.rada.gov.ua/laws/show/419-2019-p

Кремень, В.Г. (2021, 25 березня). Науковий супровід інноваційного розвитку професійної освіти [Відео]. YouTube. https://youtu.be/j-ndWiG-RAo

Лебединська, О.В. (2021, 25 березня). Розвиток проектного менеджменту в закладах професійної (професійно-технічної) освіти Луганської області [Відео]. YouTube. https://youtu.be/otQT_SJOW4k

Мірошніченко, К.Б. (2021, 25 березня). Сучасні підходи методичної і практичної підтримки діяльності закладів профресійної освіти [Відео]. YouTube. https://www.youtube.com/watch?v=di43RzW6XCw

Мірошніченко, О.В. (2021, 25 березня). Проблеми та перспективи розвитку професійної (професійнотехнічної) освіти [Відео]. YouTube. https:// youtu.be/1ueirBLO2kw

Ничкало, Н.Г. (2021, 25 березня). Iнститут профресійної (профресійно-технічної) освіти НАПН України: методологічне і професійне зростання [Відео]. YouTube. https://youtu.be/OgWyafVvwkQ

Організація Об'єднаних Націй. (2015). Цілі Сталого Розвитку. UNDP Україна. https://www.ua.undp.org/ content/ukraine/uk/home/sustainable-developmentgoals.html

Помаран, П.І. (2021, 25 березня). Напрями конструктивної взаємодії науки й освітньої практики [Відео]. YouTube. https://youtu.be/1pA2pvqqK7g

Радкевич, В.О. (2021а, 25 березня). Наукова платформа професійної освіти: сталий розвиток [Відео]. YouTube. https://youtu.be/amhz3JrJJEQ

Радкевич, В.О. (2021b). Наукова платформа професійної освіти: сталий розвиток. Вісник Начіональної академії педагогічних наук України, 3(1). https:// doi.org/10.37472/2707-305X-2021-3-1-17-1

Радкевич, В.О., \& Єршова, Л.М., наук. ред. (2021). Професійна (професійно-технічна) та фрахова передвища освіта : інформаційно-аналітичні матеріали. Житомир: «Полісся». https://bit.ly/3DE1Fm0 
Радкевич, В.О., заг. ред. (2021). Науково-методичне забезпечення професійної освіти і навчання : збірник матеріалів XV звітної Всеукраїнської науково-практичної конференції (м. Київ, 25 березня 2021 р.). Інститут професійно-технічної освіти НАПН України. Київ: ІПТО НАПН України. https://bit.ly/2YMCzlJ

Стасєєва, М.А. (2021, 25 березня). Партнерство Інституту професійної (професійно-технічної) освіти НАПН України і НМК ПТО у Київській обласmi - симбіоз науки і практики [Відео]. YouTube. https://youtu.be/-cSQyi5XYDw
Урядовий портал. (2020, 21 грудня). Колегія МОН схвалила Стратегію розвитку професійнотехнічної освіти до 2023 року. https:// www.kmu.gov.ua/news/kolegiya-mon-shvalilastrategiyu-rozvitku-profesijno-tehnichnoyi-osviti-do2023-roku

Шумік, І.В. (2021, 25 березня). Наукові підходи в реалізачії державної політики в галузі професійної освіти [Відео]. YouTube. https://youtu.be/ Fwt94E2guAw

\title{
JUBILEE CONFERENCE OF THE INSTITUTE OF INSTITUTE OF VOCATIONAL EDUCATION AND TRAINING OF NAES OF UKRAINE, DEVOTED TO THE 30TH ANNIVERSARY OF UKRAINE'S INDEPENDENCE
}

\author{
Liudmyla Bazyl \\ DSc in Pedagogy, Associate Professor, Scientific Secretary, Institute of Vocational Education \\ and Training of the National Academy of Educational Sciences of Ukraine, Kyiv, Ukraine
}

\begin{abstract}
The achievements of the Institute of Vocational Education and Training of the National Academy of Educational Sciences of Ukraine are presented. The perspective directions of realizing the Institute's priority tasks concerning the scientific and methodological support for innovative development of the system of vocational education and training, as well as professional pre-higher education are given. The achievements of the Institute's researchers in the sovereign country, interaction with VET and professional pre-higher education institutions, partner organizations, and stakeholders are characterized. The constructive collaboration with the training (scientific) and methodical centers (cabinets) of vocational education and training in Vinnytsia, Volyn, Dnipropetrovsk, Donetsk, Zakarpattia, Kirovohrad, Kyiv, Luhansk, Lviv, Mykolaiv, Odesa, Sumy, Kharkiv, Cherkasy regions is shown, which is carried out for 15 years in accordance with the signed agreements. The attention is paid to key tasks facing the modern system of vocational and professional pre-higher education, and its priorities due to the assertion of Ukraine's independence.

Keywords: professional education; vocational education and training; professional pre-higher education; Institute of Vocational Education and Training of NAES of Ukraine; scientific and methodological support.
\end{abstract}

